\title{
Discussion on "Self-Protection" Strategy of Urban Communities under Risk Society Background
}

\author{
Liang Dingcai ${ }^{1}$, Wang $\mathrm{Jia}^{2}$, Gao Yinchun ${ }^{3}$ \\ Yunnan University of Finance and Economics, Kunming, Yunnan, China \\ 1.504383479@qq.com;2.416911916@qq.com;3.446911916@qq.com
}

\begin{abstract}
The society is ever-changing nowadays. Risks such as financial crisis, terrorism, information security, typhoon and cyber crime are increasing day by day.How can capability in resisting risks of urban communities be strengthened? The thesis tries to explore "self-protection" strategies of urban communities under risk society background.
\end{abstract}

Keywords—risk society, urban community, self-protection, strategy discussion

In the 21st century, airplane crashes, train derailments, bridge collapses, bus accidents, building fires, poisoned milk, lean meat extract, poisoned bean sprouts, dyed steamed bread, and gutter oil are all common occurrences .Natural disasters and man-made disasters have led to a marked rise in people's insecurities. It can be said that today's society is a high-risk society, and the risk society has indeed come.

\section{I. "RISK” AND "RISK SOCIETY"}

According to "Modern Chinese Dictionary", "risk" means "dangers that may happen" [1].it is "risk" in English, which is from French "risque", suggesting sailing between cliffs. It can be seen that at present the academia hasn't had a uniform definition about "risks" yet.

Ulrich Beck, Wouter Achterberg, Giddens, Luhmann, etc. conducted comparatively systematic and in-depth study on "risk" and "risk society", and formed sociological theory concerning risks.Ulrich Beck summarized the concept of "risk" from eight respects, and according to his opinion, "risk doesn't refer to hazards triggered. They don't mean destruction... the concept of risk means a special and intermediate state between safety and destruction, and the understanding of menacing risks decides the thoughts and behaviors." [2]. Evidently Beck thinks modern risks are different from ancient risks from the ecological respect, and they are resulted from modernization and globalization; modern risks are uncertain and complicated. Similar to Beck, according to the "risk" theory of British Wouter Achterberg, "risk" is the inevitable result of globalization, we are shifting from a classical industrial society to a "risk" society; the "risk society" is not a choice to be chosen or refused, and it emerges from the overwhelming spontaneous modernization without considering consequences [3]. Giddens also holds the viewpoint that there are good and bad risks, but "no matter we like it or not, we have to face some risks, such as ecological disasters and nuclear war"' 4 ] .He thinks that the world we are living in now is a high-tech society, and there is nothing we can do to predict and control possible future. Meanwhile, Giddens elaborates on "risk", "danger" and "hazards", risks are classified into "external risks" and "created risks". "External risks" are external risks and risks from unchanged and stable traditions or nature, and they are dominating risks in the first two hundred years of the industrial society. People could predict, calculate and insure these external risks due to their frequent occurrence. The "created risks" refer to "risks that are generated due to the impact of the knowledge we are developing on the world". The "created risks" exist after external risks disappear, they are consequences of human development and social technological progress, which are not seen in the past, so we don't have experience and strategies to address the risks, and this will give rise to new "risks". Furthermore, this risk is "the most disturbing menace we are faced with" and the "man-made risk". As the "external risks" are transferring to "man-made risks" gradually and "man-made risks" spread, human beings enter into the risk society, and we 
are in the "risk society" [5]. By analyzing the risk theory of Beck, Luhmann thinks that risks of Beck are mainly technical risks, and he thinks that risks are existing in many social sectors and they are universal.

Look around the society: global warming, information security, network violence and crime, add water pollution, air pollution, solid waste pollution aggravate, food safety events emerge in endlessly, nuclear pollution area increase, terrorist event occurred successively, "SARS" caused panic across the country, the loss of traditional culture, and so on. The risk in today's society is no longer a matter of human safety and health, but a matter of human panorama and well-being.

The author thinks that we have entered a high-risk society, namely "risk society". Our economy is growing and our society is undergoing earth-shaking changes. However, social problems keep cropping up. It can be seen that the risk of modern society is not the product of the failure of modernization, to some extent, the product of the success of modernization. That is to say, the risk of risk society is mainly due to the globalization, social changes and distribution of wealth inequality, imperfect system, science and technology in the large-scale use of the environmental and climate change, as well as a variety of human and nonhuman bring natural changes in the disaster[6].

\section{URBAN COMMUNITY UNDER THE RISK SOCIETY BACKGROUND}

In the face of risk society, urban community mainly has the following deficiencies:

\section{A. The risk awareness and risk ability of community residents} are insufficient.

Modern people are so busy for their families and careers that the risks are forgotten. In addition, many people do not have the concept and awareness of risk. Without any previous knowledge and preparation, it is often difficult to cope with the discovery when it happens, that is lack of ability to deal with risks.

\section{B. Lack of a perfect risk mechanism}

The United Nations development program (undp) released the "China city development review report, think that China's urban development and remarkable achievements, but compared with developed countries still exist many problems and the imbalance of the development of China's urban five problems: one is of the urban agglomeration of China national wealth accumulation contribution to urban agglomeration is lower than the developed countries; Second, the role and contribution of the first city in China's urban agglomeration are low. Third, China's urban agglomeration is still in the stage of extensive economic growth. Fourth, the labor productivity of China's urban agglomeration is low. Fifth, the population density of China's urban agglomerations is too large compared with the major international urban agglomerations[7].

It can be seen that there are many problems in cities, and these problems are more social. Although the state and the government made some efforts to enhance the capacity of urban community risk defense, but the support is not enough, imperfect supporting policies, risk ability construction of urban community is still in the exploratory stage.

\section{The diversification and complexity of risks make risk management more difficult.}

There are many problems in cities, such as environment problem, traffic problem, housing problem, poverty problem, old people problem and so on. Urban environmental problems are caused by the destruction of the harmonious relationship between human economic and social development and the environment, mainly by the irrational use and waste of resources. Urban environmental problems mainly include air pollution, water pollution, noise pollution, garbage pollution, population and environment problems, economic development and urban problems, and urban environmental protection. The forms of urban traffic problems include traffic jams, accidents, public transportation, pedestrians, parking and so on. China's urban housing construction cannot meet the needs of population growth and improvement of people's living standards. The transformation of dilapidated houses and shantytowns is difficult and the reform of housing system is not ideal. It can be seen that the governance of these diversified problems is very difficult 


\section{Discussion ON "Self-Protection" STRATEGIES OF URBAN COMMUNITIES UNDER "RISK SOCIETY" BACKGROUND}

Based on a period of practical experience in the community, the author believes that social risk can only be solved by taking the initiative.

\section{A. Enhance risk awareness and risk prevention awareness}

Provide technical support to the community through publicity, education, and practice. To popularize knowledge of risk identification, risk prevention and psychological adjustment in major urban communities

\section{B. Establish a risk system for mutual assistance in the community}

First, encourage community residents to interact and communicate through various forms, and change the situation of community sand. Second, develop advantageous resources, seek other resources, and optimize the allocation of resources. Third, through the establishment of grassroots ngos, community development foundations, community mutual aid organizations, community "help" groups and other forms, the construction of urban community self-help and mutual aid system. Fourth, the state and local governments provide certain policy and financial support.

\section{Develop social workers and improve the social work service mechanism}

Social work is the government as the main body, social forces are widely participation, to give priority to do social work, sociology, psychology and other disciplines, property management, as auxiliary disciplines such as medicine, law, to help others is the core idea, in case work, group work, community work for direct work method of discipline. Social work, as a scientific helpful major, reflects its value after undergoing various tests. Relevant departments need to improve the system and vigorously develop social workers and improve the urban community social work service mechanism.

\section{Establish a response mechanism that combines government, market and society}

China's current social distribution structure like a pyramid, resources and wealth flow direction is top-down, the risk is showing the opposite direction, so the structure of the final formation of "wealth gathered in the upper, and the risk in the lower" the distribution of the state. $n$ the face of diversified and complicated risks, a governance system combining government, market and society should be constructed.

Throughout Chinese society, in recent years, with the constant improvement of the degree of social modernization and the advancement of marketization of social differentiation and increasingly serious social problems emerge in endlessly, social contradictions increasingly intensified, the norm of the society as a whole is no longer the traditional society, the social risk increases, integration of contemporary society, the traditional management method can not harmonious society faces severe challenges. In short, the world today is a risk society, and China is no exception. Faced with the risks faced by urban communities, we need to mobilize all social forces to establish a scientific defense mechanism.

\section{REFERENCES}

[1] Modern Chinese Dictionary [M]. Beijing: The Commercial Press, 2005.

[2] The Definition of Risks [EB/OL].http://baike.baidu.com/view/156901.htm. (In Chinese)

[3] Germany. Beck, World Risk Society [M]. Translated by Wu Yingzi, Su Shumin, Nanjing: Nanjing University Press, 2004.182. (In Chinese)

[4] Wouter Achterberg, Democratic, Justice and Risk Society: the Form and Significance of Ecological Democratic Politics [M].2003,3. (In Chinese)

[5] Yang Xuedong; A review on risk society theory [J].Journal of the national institute of administration,2005. (In Chinese)

[6] Analysis of Risks of Modern Society, Zhejiang Social Sciences, January 2005 (In Chinese)

[7] YangXuedong, Composite Governance Required for Global Risk Society [EB/OL].http://www.cass.net. cn/webnew/file/, 2005-01-13. (In Chinese) 